ATC ANNALS JOURNAL CLUB:

\title{
The 'Yield' of Targeted Screening for Type 2 Diabetes
}

Ann Fam Med 2009;7:iii. doi:10.1370/afm.1039.

The Annals of Family Medicine encourages readers to develop a learning community of those seeking to improve health care and health through enhanced primary care. You can participate by conducting a RADICAL journal club and sharing the results of your discussions in the Annals online discussion for the featured articles. RADICAL is an acronym for Read, Ask, Discuss, Inquire, Collaborate, Act, and Learn. The word radical also indicates the need to engage diverse participants in thinking critically about important issues affecting primary care and then acting on those discussions. ${ }^{1}$

\section{HOW IT WORKS}

In each issue, the Annals selects an article or articles and provides discussion tips and questions. We encourage you to take a RADICAL approach to these materials and to post a summary of your conversation in our online discussion. (Open the article online and click on "TRACK Comments: Submit a response.") You can find discussion questions and more informait tion online at: http://www.AnnFamMed.org/AJC/.

\section{CURRENT SELECTION}

\section{Article for Discussion}

Klein Woolthuis EP, de Grauw WJC, van Gerwen WHEM. Yield of opportunistic targeted screening for type 2 diabetes in primary care: the Diabscreen study. Ann Fam Med. 2009;7(5):422-430.

\section{DISCUSSION TIPS}

Although screening for diabetes is not recommended for the general population, a great deal of case finding for diabetes occurs through tests ordered for various reasons. The article by Klein Woolthuis and colleagues in this issue can be used to stimulate consideration of whether and how to screen for type 2 diabetes.

\section{DISCUSSION QUESTIONS}

- What question is addressed by the article? How does the question fit with what already is known on this topic?

- How strong are the study design and data source for answering the question?

- To what degree can the findings be accounted for by:

1. How participants were selected?

2. How outcomes were measured?

3. Confounding (false attribution of causality because two variables discovered to be associated actually are associated with a 3 rd factor)?

4. Chance?

- What are the main findings?

- How comparable is the study population to your practice, and how does this effect the transportability of the findings?

- How might the high-risk groups be different if the study were done in US family practices?

- How relevant are the findings to consideration of screening for the general population?

- How do the recommendations of the US Preventive Services Task Force ${ }^{2}$ and the American Diabetes Association $^{3}$ inform your consideration of these findings? How and why do these recommendations differ?

- How (if at all) does this study change your practice?

- What important researchable questions remain?

\section{References}

1. Stange KC, Miller WL, McLellan LA, et al. Annals Journal Club: it's time to get RADICAL. Ann Fam Med. 2006;4(3):196-197. http:// annfammed.org/cgi/content/full/4/3/196.

2. US Preventive Services Task Force. Screening for Type 2 Diabetes Mellitus in Adults. June, 2008. http://www.ahrq.gov/CLINIC/uspstf/ uspsdiab.htm. Accessed Jul 25, 2009.

3. American Diabetes Association (ADA). Standards of medical care in diabetes. II. Testing for pre-diabetes and diabetes in asymptomatic patients. Diabetes Care. 2008;31(Suppl 1):S13-S14. http://care.diabetes journals.org/content/31/Supplement_1/S12.full. Accessed Jul 25, 2009. 